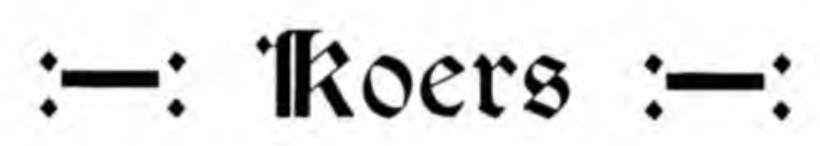

TWEEMAANDELIKSE TYDSKRIF

\begin{tabular}{lll}
\hline JAARGANG XXIII & JUNIE 1956 & No. 6 \\
\hline
\end{tabular}

\title{
SAMEWERKING TUSSEN CALVINISTIESE UNIVERSITEITE VAN SUID-AFRIKA, NEDERLAND EN AMERIKA *
}

As konfessionele universiteit op Calvinistiese grondslag voel die P.U. vir C.H.O. homself nou verwant en verbonde aan die Vry Universiteit te Amsterdam. Dit spreek egter vanself dat elkeen van die twee universiteite 'n eie nasionele grondslag het en in diens staan van sy eie volk. Tog is daar soveel gemeenskaplik dat die twee inrigtings daadwerklik pogings behoort aan te wend om saam te werk, van mekaar te leer en saam die Christelike wetenskap op te bou. Graag wil ons hierby ook Calvin College van Grand Rapids, Amerika, insluit. Met die bydrae vanuit hierdie drie inrigtings kan 'n wetenskaplike sisteem of sisteme opgebou word met 'n wye omvang en inslag, en met verdere ondersteuning van indiwiduele Calvinistiese wetenskaplikes uit ander akademiese inrigtings kan die Christelike wetenskap onweerstaanbaar op die mars kom.

Aangesien hierdie samewerking nie maar net aan sporadiese en seldsame geleenthede oorgelaat kan word nie, volg hier nou 'n paar praktiese wenke wat nie alleenlik vir die betrokke universiteite nie, maar ook vir die volke in wie se diens hulle staan, van groot waarde kan wees.

(i) Uitruiling van wetenskaplike dissertasies en geskrifte. Dit behoort 'n vaste gebruik te wees om die biblioteke van die drie inrigtings te verryk

*Uitreksel uit 'n rede gehou voor die professorekrans van die Vrye Universiteit deur die skrywer. 
met elke dissertasie wat aanvaar word en elke wetenskaplike publikasie van die dosente. Die voordele lê voor die hand, maar die grootste voordeel sal waarskynlik wees die konstante kennisname en waardering van die werk wat in al drie die inrigtings gedoen word en die geleentheid vir intieme kritiek in eie kring, iets wat besonder goeie vrugte kan afwerp. Desnoods kan in elke biblioteek 'n spesiale afdeling vir die dissertasies en publikasies van die ander inrigtings geskep word wat dan as die V.U.- of Calvin Collegeof P.U. vir C.H.O.-afdeling bekend kan staan.

(ii) Uitruiling van dosente. Graag wil ek hierdie direkte metode van kontak sterk beklemtoon. Al is dit net vir kort periodes is dit noodsaaklik dat dosente van die drie inrigtings mekaar wedersyds sal besoek en 'n reeks kolleges voor studente gee veral oor spesialiteits-onderwerpe. Vir die studente is dit van ontsaglik veel waarde om van so 'n besoekende dosent te leer, maar meer nog sal dit 'n stimulus vir dosente wees om suster-inrigtings te besoek en besoekers te ontvang, om sodoende gesigspunte uit 'n ander maar verwante oord te verneem. Nie alleenlik voorsien ek voordele in 'n enger akademiese kring nie, maar ook 'n wyer en suiwerder blik op lands- en volksomstandighede. As die wil hiervoor maar net eers daar is, sal die weg, ook op finansiële gebied, wel gevind kan word.

(iii) Publikasie van artikels in die tydskrifte wat verbonde is aan die inrigtings. Hier dink ons veral aan „Koers”, wat dit sal verwelkom om Nederlandse en Amerikaanse Calviniste aan Suid-Afrikaanse lesers bekend te stel.

(iv) Die instelling van 'n leerstoel vir Afrikaanse taal, letterkunde en kultuurgeskiedenis aan die Vrye Universiteit en Calvin College. Daar is geen beter metode van kontak denkbaar om samewerking tussen Calviniste in die drie lande te bewerkstellig as juis om die Calvinistiese jeug van Nederland en die V.S.A. in geleentheid te stel om eerstehands kennis met die Afrikaanse taal en kultuur te maak nie. Dit sou elke land ook konfronteer met 'n gesaghebbende Afrikaner-standpunt ten opsigte van Suid-Afrikaanse aangeleenthede en probleme. Met 'n Calvinistiese dosent uit Suid-Afrika ter plaatse kan 'n welwillendheid jeens en ware perspektief van Suid-Afrika opgebou word in daardie kringe waarin ons 'n besondere belangstelling koester, nl. die Calvinistiese bevolkingsgroepe van Nederland en Amerika. 'n Ideale toestand sou juis wees om in hierdie verband 'n uitruiling van leerkragte op langer termyn te laat plaasvind. So kan bv. 'n dosent van die P.U. vir C.H.O. uit die departement Afrikaans-Nederlands aan die Vrye Universiteit of Calvin College vir 'n tydlank die leerstoel vir Afrikaans 
waarneem, terwyl 'n Nederlandse dosent van die V.U. Nederlandse kultuurgeskiedenis en 'n Amerikaanse dosent van Calvin College Amerikaanse kultuurgeskiedenis aan die P.U. vir C.H.O. kan waarneem. Dink maar aan die nuwe gesigspunte en insig wat soiets kan bewerkstellig!

Is dit nou te optimisties om so 'n samewerking tussen die enigste drie Calvinistiese universiteite in die wêreld vir die toekoms in vooruitsig te stel?

W. N. COETZEE. 